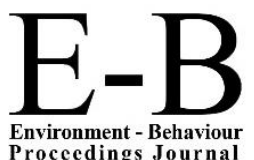

Environment - Behaviour
Procecdings Journal
AIVCE-BS-2, 2020ShahAlam

https://www.amerabra.org; https://fspu.uitm.edu.my/cebs; https://www.emasemasresources.com/ AMEABRA International Virtual Conference on Environment-Behaviour Studies, $2^{\text {nd }}$ Series cE-Bs, FSPU, Universiti Teknologi MARA, Shah Alam, 02-03 Dec 2020

\section{e-IPH}

e-International Publishing House Ltd. United Kingdom

\title{
Accounting Students' Motivation for Getting Professionally Qualified
}

\author{
Melissa Mam Yudi, Nurul Nadiah Ibrahim, Siti Aisyah Kamaruzaman, \\ Nur Quratun 'Aini Haron, Nazreen Sahol Hamid, Siti Syaqilah Hambali
}

Department of Professional Accounting Studies, Faculty of Accountancy, Universiti Teknologi MARA, Shah Alam, Malaysia

melissamamyudi@uitm.edu.my, nurul0068@uitm.edu.my, aisyah9985@uitm.edu.my, quratun9969@uitm.edu.my, nazreensahol@uitm.edu.my, syaqilah9972@uitm.edu.my

Tel: +60123889206

\begin{abstract}
To move Malaysia to a developing nation, 60,000 professionally qualified accountants are needed by 2030 . However, as of April 2017, only 33,000 accountants have registered as members of the Malaysian Institute of Accountants (MIA). The purpose of this research is to analyse students' behaviour on the motivational factors to obtain professional accounting qualifications. This study gathered the response of 187 students as samples from the only public university in Malaysia that offers ACCA professional accounting certificate. The results show that most students are motivated by intrinsic and extrinsic motivations, while there is no relationship between third parties' influence and demographic factors with the decision to pursue a professional accounting qualification.
\end{abstract}

Keywords: Professional qualified; intrinsic motivation; extrinsic motivation; accounting students

eISSN: 2398-4287@ 2020. The Authors. Published for AMER ABRA cE-Bs by e-International Publishing House, Ltd., UK. This is an open access article under the CC BYNC-ND license (http:///creativecommons.org/licenses/by-nc-nd/4.0/). Peer-review under responsibility of AMER (Association of Malaysian Environment-Behaviour Researchers), ABRA (Association of Behavioural Researchers on Asians) and CE-Bs (Centre for Environment-Behaviour Studies), Faculty of Architecture, Planning \& Surveying, Universiti Teknologi MARA, Malaysia.

DOI: https://doi.org/10.21834/ebpj.v5i15.2454.

\subsection{Introduction}

In the year 2010, Malaysia's Prime Minister in service, Dato' Sri Mohd Najib Tun Abdul Razak announced the launch of the National Transformation Programme (hereafter NTP) to move Malaysia as a developing nation, to another level of high-income nations (Performance Management and Delivery Unit (PEMANDU), 2010). In an effort to propel the country in reaching this aim, it is expected that 60,000 professional accountants are to be produced by year the 2030 as part of the profession's contribution to support nation-building (Malaysian Institute of Accountants, 2018, 2019).

The International Federation of Accountant (IFAC) describes professional accountant as a person who has expertise in the field of accountancy, achieved through formal education, practical and experience. It is also further defined as someone who is subjected to enforcement by a professional accountancy organisation or other regulatory mechanisms (IFAC, 2011).

In Malaysia, the accountant profession is regulated by a statutory body called the Malaysian Institute of Accountants (MIA), which was established under the Accountants Act of 1967. It is required for a person to obtain the necessary qualifications and 3 years of experience in an accounting-related field before being called as a member of MIA and declaring themselves as a Chartered Accountant. Various international professional accounting qualifications, such Association of Chartered Certified

eISSN: 2398-4287@ 2020. The Authors. Published for AMER ABRA cE-Bs by e-International Publishing House, Ltd., UK. This is an open access article under the CC BYNC-ND license (http://creativecommons.org/licenses/by-nc-nd/4.0/). Peer-review under responsibility of AMER (Association of Malaysian Environment-Behaviour Researchers), ABRA (Association of Behavioural Researchers on Asians) and cE-Bs (Centre for Environment-Behaviour Studies), Faculty of Architecture, Planning \& Surveying, Universiti Teknologi MARA, Malaysia. DOI: https://doi.org/10.21834/ebpj.v5i15.2454. 
Accountants (ACCA)(UK), the Institute of Chartered Accountants in England and Wales (ICAEW) are supported for MIA membership (First Schedule, Section 14 and 15, Accountants Act 1967).

As of the year 2017, the total number of registered MIA members in the country is only at 33,000, which suggests the number as far from the goal of NTP (ACCA, 2018). Thus, this study aims to examine the factors that influence students' choice in pursuing a professional accounting qualification after secondary school, and to uncover the existence of any relationship between demographic factors and their decision to pursue this qualification. This study focuses on intrinsic motivation, extrinsic motivation and the influence of third parties.

This study can provide information to universities, professional bodies and the Ministry of Higher Learning on areas of improvement when designing recruitment strategies and in an effort to examine the resources on addressing the shortage of professionally qualified accountants in Malaysia. In addition, it may contribute to the viability of any professional body as every progress largely depends on their ability to continuously attract ideally of the best and brightest new tertiary graduates (Malthus, and Fowler, 2009).

\subsection{Literature Review}

This section will briefly cover the factors influencing students' decision to pursue professional accounting qualifications, namely intrinsic motivation, external motivation and influence of third parties. It also covers literature reviews on demographic factors affecting the students' decision.

\subsection{Intrinsic Motivation}

The emphasis on the motivational factors appears in two forms, which are intrinsic motivation and extrinsic motivation (Ryan \& Deci, 2000). The most basic distinction is between intrinsic motivation, which refers to doing something because it is inherently interesting or enjoyable. Intrinsic motivation includes two components, namely personal interest and personal choice. Initially, when a student is found to have control of his own life, actions, and choices, it increases his motivation and interest.

A previous study conducted by Odia and Ogiedu (2013) found that personal factors such as students' interest and motivation in the subject are the most influencing factors of students' choice of accounting. Based on the 300 data gathered from Nigerian Universities, students prefer accounting simply because of its criteria as an interesting subject, and they are addicted to numbers and figures. These factors had intrinsically motivated students to study accounting.

Other than that, a past study conducted by Hutaibat (2012) explores perceptions of the final year accounting students of two reputable Jordanian universities regarding their interest in management accounting profession. Based on 118 questionnaires data collected, they found that the heavy workload in such courses could significantly reduce students' interest, and the nature of such courses could be difficult not enjoyable or less interesting for many students; thus, reduce students' intrinsic motivation to pursue management accounting profession.

Meanwhile, Ghani, Said, Nasir, and Jusoff (2009) studied relating on factors perceived to be important in the accounting profession choices. Based on 802 questionnaires responses received, the result shows that self-interest is the most popular reason in studying accounting for the Malaysian public university students. Therefore, this leads to the following hypothesis:

\section{Hypothesis 1: There is a positive relationship between intrinsic motivation and accounting professional qualification.}

\subsection{Extrinsic Motivation}

Extrinsic motivation can be distinguished from intrinsic motivation, where it pushes individuals to perform some tasks for some expected rewards such as wages, employment securities, and career progression. The orientation of motivation underlies the reason for attitudes and actions taken by individuals (Ryan \& Deci, 2000). People with intrinsic motivation is doing their job based on the enjoyment of the tasks itself, and people with intrinsic value performs each task for its external outcome rather than because of the job per se.

Santos, Moura, and Almeida (2018) suggested that extrinsic motivation is one of important factors in influencing students' decision to pursue a professional accounting qualification in Ghana. There is a study that found that students who intended to pursue professional accounting jobs placed significantly greater importance on financial reasons (Dalci, Arasli, Tümer, \& Baradarani, 2013). Hutaibat (2012) suggested that job opportunities influence students' decisions to pursue an accounting career. As the current economy is becoming more challenging, students need to consider the broad job opportunities in determining their future career paths.

However, previous studies are suggesting that there is no association between extrinsic motivation and students' career choices (Pratama \& Padjadjaran, 2017, and Law, 2010). Pratama and Padjadjaran (2017) stated that, it is embedded as students' perceptions, where any accounting profession could provide a similar benefit that professional accountancy qualification can offer.

Hypothesis 2: There is a positive relationship between extrinsic motivation and accounting professional qualification. 


\subsection{Influence of Third Parties}

Student's decisions regarding their career path can also be influenced by individuals such as family members, peers, career counsellors and teachers. This can be evidenced more in Asian cultures as there is a strong relationship between parents and their children. Thus, the findings of previous studies have found that it is often for students to be influenced by parents' opinion regarding their career choices.

Law (2010) and Hsiao (2015) suggested that parental opinion affects students' decision to pursue professional accounting qualification. In Indonesia, a study found that accounting students were highly influenced by their parents compared to other third parties such as their friends or government (Pratama \& Padjadjaran, 2017). There are arguments about the influence of third parties on students' decisions on career choices.

Apart from that, Owusu et.al (2018) studied that parents seem to have a greater influence on the intentions of students to pursue accounting profession. The educational background of parents influences students' selection of which subject area to specialise in higher education, including accounting. According to Bekoe et. al (2018), it is common scenario for parents and other elderly to decide on behalf of a student who they may be associated with, even at the tertiary level particularly when it comes to their career decisions. Thus, parents, relatives, teachers and other agents of the society are keys in determining the kind of career path a student will chart. Hence, this situation highlights their crucial influence in shaping students' decision to pursue a course. Based on the previous research, we can propose hypothesis as follows:

Hypothesis 3: There is a positive relationship between the influence of third parties and accounting professional qualification.

\subsection{Demographic Factors}

Demographics factors had their contribution to professional accounting qualification choices among students. In public universities of Malaysia, female students are more than male. However, according to Stuart and Gonzalez (2016), student's number is classified under the topic of gender-neutral. Accounting qualifications are a male dominated profession, but it is changing slowly over time. Stuart and Gonzalez (2016) found out that ICAEW has the largest percentage of male members with $73 \%$ and $78 \%$ respectively. CPA Australia has the least gender discrepancy with $53 \%$ male and $47 \%$ female members. Beverly and Claude (2006) found that there is no significant difference between women and men to become accountants, and this is contradicted with Nelson and Vendrzyk's research (1996) result which shows women have a greater interest rate than the male students in the USA.

\section{Hypothesis 4: There is a positive relationship between demographic with a professional accounting qualification}

Thus, the literature review confirms the theme of all 4 variables in the questionnaires constructed as the contributing factors that influenced students to choose professional accounting qualifications. According to Kapoor and Chan (1985), accountants should be broadly educated as well as being technically competent. By choosing a professional accounting qualification, they should be more competent and marketable; this indirectly increases the quality of life as the field provides career growth.

\subsection{Methodology}

\subsection{Participants and Procedures}

This study is conducted in the only public university in Malaysia that offers professional accounting studies, which is Universiti Teknologi MARA, Shah Alam. The institution is selected as it represents the only public university in Malaysia which was accredited with Platinum Status as tuition provider by ACCA. This study chose new students who further their study in professional accounting qualifications, namely Certified Accounting Technician (hereafter CAT) and Association of Chartered Certified Accountants (ACCA) as the sample study. The novelty of this paper is determined through the sample study, which is purely students who are taking professional accounting qualifications instead of basic accounting qualifications (i.e.: Diploma in Accounting and Bachelor of Accountancy).

\subsection{Research Instrument}

The primary data was collected through questionnaires survey. The questionnaires were distributed to new students in the department of professional accounting studies UiTM Shah Alam. 187 valid data were then used for further research analysis. This study comprises of 4 variables namely intrinsic motivation, extrinsic motivation, influence by the third party, and accounting professional qualification. A Likert scale's agreement was used in the questionnaire that have the rank order from strongly disagree (scale 1) to strongly agree (scale 5). This study adopted the quantitative data analysis technique and engaged in both descriptive and inference statistics. In this study, 187 questionnaires were distributed and from the returned questionnaires, no set was rejected, resulting in a $100 \%$ response rate.

The questionnaire on independent variables was constructed and adapted based on studies by Odia and Ogiedu (2013), Hutaibat (2012) and Ghani et al. (2008), while dependent variable was adapted from Mustapha (2012) are shown in Table 1. 
Table 1. Research variables and measurements

\begin{tabular}{|c|c|}
\hline Research Variables & Measurements \\
\hline \multirow[t]{6}{*}{ Intrinsic motivation } & I know accounting \\
\hline & I like accounting \\
\hline & Accounting is interesting \\
\hline & I would enjoy being an accountant \\
\hline & I am willing to spend a lot of time studying accounting \\
\hline & I can do better in calculation \\
\hline \multirow[t]{5}{*}{ Extrinsic motivation } & $\begin{array}{l}\text { I choose accounting course because there will be jobs available for me } \\
\text { when I graduated }\end{array}$ \\
\hline & $\begin{array}{l}\text { I choose accounting course because there will always be a great job } \\
\text { market demands for people like me }\end{array}$ \\
\hline & $\begin{array}{l}\text { I can get high-paying job if I graduate with accounting professional } \\
\text { qualifications }\end{array}$ \\
\hline & Being an accountant has a lot of prestige \\
\hline & The accounting profession is well respected \\
\hline \multirow[t]{5}{*}{ Influence by third parties } & $\begin{array}{l}\text { My family and friends have a high influence on my professional } \\
\text { accounting studies decisions }\end{array}$ \\
\hline & $\begin{array}{l}\text { I am strongly influenced by the educators on my choice of professional } \\
\text { accounting studies decisions }\end{array}$ \\
\hline & $\begin{array}{l}\text { I am strongly influenced by the media on my choice of professional } \\
\text { accounting studies decisions }\end{array}$ \\
\hline & $\begin{array}{l}\text { I am strongly influenced by the public/society on my choice of } \\
\text { professional accounting studies decisions }\end{array}$ \\
\hline & $\begin{array}{l}\text { I am strongly influenced by the school counsellor on my choice of } \\
\text { professional accounting studies decisions }\end{array}$ \\
\hline \multirow[t]{4}{*}{ Accounting Professional Qualification } & I clearly want to have professional qualifications \\
\hline & I clearly know my choice of career upon my graduation \\
\hline & $\begin{array}{l}\text { I understand the career options available to me (e.g. tax assistant, } \\
\text { audit assistant, costing assistant, and accounts assistant) }\end{array}$ \\
\hline & $\begin{array}{l}\text { I clearly know my choice of professional body (e.g.: ACCA, CPA, } \\
\text { MICPA, CIMA) }\end{array}$ \\
\hline
\end{tabular}

\subsection{Findings}

\subsection{Demographic Profile}

The summary of the respondents' profile is highlighted in Table 2. The respondents' demographic profile includes gender, age and entry point to the professional programme (CAT and ACCA). There are few entry points to a professional qualification depending on the educational background of the students. Students who are fresh from high school would have to complete the foundation level, which is known as CAT and thereafter, continue to ACCA. The entry requirement to CAT would be Sijil Mata Pelajaran Malaysia (SPM) but for ACCA qualification, there are more entry points which include matriculation, diploma and bachelor programmes.

Table 2. Demographic profile of respondents

\begin{tabular}{llll}
\hline Profile & Category & Frequency & $\%$ \\
\hline Gender & Male & 68 & 36.4 \\
& Female & 119 & 63.6 \\
Age & $16-20$ & 176 & 94.1 \\
& $21-25$ & 11 & 5.9 \\
\multirow{3}{*}{ Entry Point } & 26 and above & 0 & 0 \\
& Sijil Mata Pelajaran & 112 & 59.5 \\
& Malaysia & & \\
& Matriculation & 59 & 31.6 \\
& CAT & 7 & 3.7 \\
Professional Accounting Programme & Diploma & 3 & 1.6 \\
& Bachelor & 6 & 3.2 \\
& CAT & 113 & 60.43 \\
& ACCA & 74 & 39.57 \\
\hline
\end{tabular}

\subsection{Measuring Relationships between Variables}

Table 3 shows the result of the Pearson Correlation Analysis. Since the value of each correlation between each variable is below 0.9 , there is no multicollinearity problem (Saunders et al, 2009). Multicollinearity occurs when two or more independent variables are highly correlated with each other. Based on Table 3, the highest correlation is between the independent variable and the dependent variable is 0.408 . Since it is less than 0.9 , thus the multicollinearity problem does not exist. 
Table 3. Pearson Correlation Analysis Result

\begin{tabular}{lllll}
\hline & $\begin{array}{l}\text { Intrinsic } \\
\text { Motivation }\end{array}$ & $\begin{array}{l}\text { Extrinsic } \\
\text { Motivation }\end{array}$ & $\begin{array}{l}\text { Influence of Third } \\
\text { Parties }\end{array}$ & $\begin{array}{l}\text { Professional } \\
\text { Qualification }\end{array}$ \\
\hline Intrinsic Motivation & 1 & & & \\
Extrinsic Motivation & 0.433 & 1 & & \\
Influence of Third Parties & 0.236 & 0.265 & 1 & 1 \\
Professional Qualification & 0.408 & 0.42 & 0.191 & 1 \\
\hline
\end{tabular}

Table 4 shows the multiple regression analysis results. The purpose of performing a regression analysis is to determine the contribution percentage of each independent variable on the dependent variables. Based on Table 4 , it presents the summary of the multiple linear regression model. The R2 value is 0.242 , which indicates that $24.2 \%$ of the variation in professional qualification can be explained by the variation of intrinsic motivation, extrinsic motivation and influence by the third party. The following prediction model is formed:

\section{Accounting Professional Qualification $=5.700+0.213(\mathrm{IM})+0.252(\mathrm{EM})+0.252(\mathrm{ITP})$}

Table 4. Multiple regression analysis result

\begin{tabular}{lccccc}
\hline Model & $\begin{array}{c}\text { Unstandardized } \\
\text { B }\end{array}$ & $\begin{array}{c}\text { Coefficients } \\
\text { Std. Error }\end{array}$ & $\begin{array}{c}\text { Standardized } \\
\text { Coefficients } \\
\text { Beta }\end{array}$ & t-value & Sig. \\
\hline (Constant) & 5.700 & 1.502 & & 3.795 & 0.000 \\
Intrinsic Motivation & 0.213 & 0.057 & 0.271 & 3.754 & 0.000 \\
Extrinsic Motivation & 0.252 & 0.063 & 0.291 & 4.002 & 0.000 \\
Influence of Third Parties & 0.031 & 0.041 & 0.050 & 0.739 & 0.461 \\
R $^{2}$ & 0.242 & & & & \\
Adjusted R ${ }^{2}$ & 0.230 & & & & \\
F-Value & 19.525 & & & & \\
Sig. F & 0.000 & & & & \\
\hline
\end{tabular}

\subsection{Discussion}

\subsection{Intrinsic Motivation}

From Table 4, it is evident that two out of three independent variables have $p$-values less than 0.05 . The first is intrinsic motivation, whereby students who have an internal drive and interest in the subject matter, in this case, accounting, are more inclined to pursue a professional accounting qualification. Having intrinsic motivation would allow a student to work hard in succeeding in his or her choice of higher education path, and later develop expertise. This is consistent with previous studies by Ghani et al. (2009) and Odia and Ogiedu (2013).

However, the results of this study are inconsistent with Hutaibat (2012), as pursuing a professional qualification would require a thorough understanding of answering techniques and comprehensive practice of past examination questions (Mam Yudi et al., 2018). This suggests that even though students will be faced with a heavy workload throughout their studies, they still decide to take on the challenge and pursue a professional accounting qualification. Therefore, the variables of null hypothesis for intrinsic motivation is rejected.

Hypothesis 1: There is a positive relationship between intrinsic motivation and accounting professional qualification (Accepted)

\subsection{Extrinsic Motivation}

The second independent variable which has a p-value of less than 0.05 is extrinsic motivation. The results of this study suggest that students are motivated by the prestige and demand of the accounting profession, which are offered upon their successful completion of studies (Ryan \& Deci, 2008). A high paying salary and job security are the driven factors for them to pursue a professional accounting qualification.

In a fast-paced era, such as now, students want a qualification that would equip them with the necessary knowledge and skills to ensure marketability. By pursuing a professional qualification, students rest assured on this matter as the professional body, which is ACCA will ensure that the syllabus is always up to date with any changes in the industry. This finding is consistent with Hutaibat (2012) but inconsistent with a previous study by Pratama and Padjadjaran (2017), which suggests that, there is no relationship between extrinsic motivation and pursuing an accounting career. Thus, we can conclude that extrinsic motivation has a positive relationship with accounting professional qualification.

Hypothesis 2: There is a positive relationship between extrinsic motivation and accounting professional qualification (Accepted) 


\subsection{Influence of Third Parties}

In contrast, the influence of third parties shows a p-value of more than 0.05 . The results indicate that students are not influenced by their parents as previously studied by Law and Hsiao (2015), Pratama and Padjadjaran (2017), Owusu et al. (2018) and Bekoe et al. (2018). In most literature, the main influence from third parties is usually from those who have a close relationship with the students' such as the parents, relatives, or their teacher.

This suggests that, other third-parties who have no previous connection with the students' (i.e. the professional body itself or government) are responsible in playing a role in educating and attracting the young generation to pursue professional accounting qualifications. This would allow potential students to make their own informed decision, instead of just relying on close parties for guidance. Thus, the variables null hypothesis is accepted, when the influence of third parties does not show any significant relationship with accounting professional qualification.

Hypothesis 3: There is a positive relationship between the influence of third party and accounting professional qualification (Rejected)

\subsection{Demographic Factor}

In this study, we use an Independent Sample t-test to test whether there is any significant difference between the independent variable (demographic) and the dependent variable. Independent sample t-test was used to test the demographic profile (gender).

Based on Table 5, it shows that there are more female students pursuing accounting professional qualification (mean: 16.74, SD: 1.944) compared to male students (mean: 16.74, SD: 1.944). This is consistent with a previous study by Said et al. (2004), which found that higher learning institutions have more female students as compared to male students.

Levene Test (Table 6) was also conducted and the result shows that the $p$-value is more than $0.05(p=0.328)$, which indicates the equal variances that been met. Thus, the T-test of equality of means is conducted and the result shows that there is no significant difference as the $p$-value is more than $0.05(p=0.096)$.

This appears to be consistent with Stuart and Gonzalez (2016), and Beverly and Claude (2006), where it was found that there is no significant difference between women and men accountants, as the profession has slowly become more gender neutral. Therefore, we can conclude that demographic factors do not have a significant relationship with accounting professional qualification.

Hypothesis 4: There is a positive relationship between demographic with professional accounting qualification (Rejected)

\begin{tabular}{llll}
\multicolumn{4}{c}{ Table 5. Descriptive statistics of gender } \\
\hline Gender & $\mathrm{N}$ & Mean & Std. Deviation (SD) \\
\hline Male & 68 & 16.74 & 1.944 \\
Female & 119 & 17.29 & 2.282 \\
\hline
\end{tabular}

Table 6. Independent t-test results

\begin{tabular}{lcccccc}
\hline & \multicolumn{3}{c}{$\begin{array}{l}\text { Levene's Test for Equality of } \\
\text { Variances }\end{array}$} & \multicolumn{4}{c}{ t-test for Equality of means } \\
& $\mathrm{F}$ & Sig. & $\mathrm{t}$ & $\mathrm{dF}$ & Sig. (2-tailed) & $\begin{array}{c}\text { Mean } \\
\text { Difference }\end{array}$ \\
$\begin{array}{l}\text { Equal variances } \\
\text { assumed }\end{array}$ & .961 & .328 & -1.672 & 185 & .096 & -.550 \\
\hline
\end{tabular}

\subsection{Conclusion and Recommendations}

This paper aims to investigate factors that influence students' choice in pursuing a professional accounting qualification and the existence of any relationship between demographic factors and their decision to pursue this qualification. This study has directed its focus on intrinsic motivation, extrinsic motivation and the influence of third parties.

Intrinsic motivation and extrinsic motivation play their significant role in students' choice to pursue a professional accounting qualification. For intrinsic motivation, it is suggested that though the students are aware of the challenging and rigorous study process that they would have to endure, they are still interested to pursue this qualification. As for extrinsic motivation, the promise of a good job prospect in the industry is one of the popular reasons for them in choosing this requisite qualification. The findings suggest that students are more influenced by extrinsic motivation compared to intrinsic motivation. This maybe because, they prioritise careers that build their future above the things they personally enjoy, considering professional certificate to be globally recognised and has better jobs prospects in both locally and internationally (Owusu et al., 2018).

Indicators such as demographics and the influences of the third party are among the insignificant factors of students' decision to pursue a professional accounting qualification. According to the previous studies, the interest of family members 
and friends does not influence students' decisions regarding their career path. One of the demographic factors is the gender of the respondents. It could come from the fact that accounting professional jobs are suitable for both sexes.

These findings may be useful for accounting education institutions in cultivate an interest towards accounting programme among students in their early stages. Besides, the involvement of accounting professionals in the curricula design could provide a broad insight into the profession and perhaps could motivate them by giving real-life examples of the accountancy career. The strong network will not just benefit the students but also the institution, as it will create a synergistic relationship between both parties. Furthermore, this study should benefit the professional accounting bodies in designing the promotion programme in a way to increase the awareness of accounting students regarding every potential profession. Professional bodies such as CIMA, ACCA and MIA may consider in giving exposure to students through talks, network events and sharing success stories to inculcate the students' interest in pursuing professional accounting qualification.

One of the limitations of this paper is that the study is based at a single public institution, thus does not allow for wider generalisation on an insight into the career decision making of Malaysian students. Perhaps, future researchers would want to include more public and private institutions as a sample for their studies. Other than that, future researches could be done in other different methods. A structured interview session can be used to increase the accuracy of the data collected. Besides, future researchers could discover new factors that were not yet being noticed from the previous studies.

\section{Acknowledgements}

We would like to thank the Faculty of Accountancy, UiTM for guidance and financial support. We also would like to thank professional accounting students of UiTM Shah Alam who had participated in this study as respondents.

\section{Paper Contribution to Related Field of Study}

This study outlines the critical areas that both universities and qualified accounting bodies can concentrate on to enhance the design of enrolment and recruitment strategies. It also fulfils the established need to research how the shortfall of qualified professional accountants in Malaysia can be addressed. Other than that, as we understand the behaviour of students' motivation, it indirectly increases the quality of life as it provides future career growth to the students.

\section{References}

(IFAC), I. F. (2011, February 6-8). A Proposed Definition of 'Professional Accountant'. Retrieved from https://www.ifac.org/system/files/meetings/files/5890_0.pdf

Abdullah, M., \& Zakaria, Z. (2006). Desired Attributes of Public Accounting Firms from Accounting Students' Perceptions: The Case of University of Malaya \& International Islamic University of Malaysia. Journal of Financial Reporting and Accounting, 4(1), 25-37. Retrieved from https://doi.org/10.1108/19852510680001582

ACCA. (2018). The Drive to Double Malaysia's Accountancy Profession by 2020 Retrieved from https://www.accaglobal.com/sg/en/member/member/accounting-business/2018/03/practice/malaysia-2020.html

Bekoe, R., Owusu, G., Ofori, C., Essel-Anderson, A. and Welbeck, E. (2018), "Attitudes towards Accounting and Intention to Major in Accounting: A Logistic Regression Analysis", Journal of Accounting in Emerging Economies, Vol. 8 No. 4, pp. 459-475

Beverly, J., \& Claude, C. (2006). Influences on Undergraduate Students' Intentions to become Qualified Accountants: Evidence from Australia. Journal Accounting Education, 15(4), 419-438

Dalci, I., Arasli, H., Tümer, M., \& Baradarani, S. (2013). Factors that Influence Iranian Students' Decision to Choose Accounting Major. Journal of Accounting in Emerging Economies, 3(2), 145-163. Retrieved from http://dx.doi.org/10.1108/20421161311288866

DeCarlo, L.T. (1997) On the Meaning and Use of Kurtosis. Psychological Methods, American Psychological Association, 2, 292-307

Field, A. P. (2013). Discovering Statistic Using SPSS: And Sex and Drugs and Rock 'n" Roll (4th edition ed.). London: Sage.

George, D., \& Mallery, P. (2003). SPSS for Windows Step by Step: A Simple Guide and Reference (4 ed.)

George, D. and Mallery, P. (2010) SPSS for Windows Step by Step: A Simple Guide and Reference 17.0 Update. 10th Edition, Pearson, Boston

Ghani, E. K., Said, J., Nasir, N. M., \& Jusoff, K. (2009). The 21ST Century Accounting Career from the Perspective of the Malaysian University Students. Asian Social Science. https://doi.org/10.5539/ass.v4n8p73

Hsiao, J. (2015). Generational Approach to the Factors Influencing Career Choice in Accounting. Contabilidade e Controladoria No Seculo XXI

Hutaibat, K. A. (2012). Interest in the Management Accounting Profession: Accounting Students' Perceptions in Jordanian Universities. Asian Social Science. https://doi.org/10.5539/ass.v8n3p303 
Ishola, A., Adeleye, S., \& Tanimola, F. (2018). Impact of Educational, Professional Qualification and Years of. Journal of Accounting and Financial Management, 4(1), 36. doi:ISSN 2504-8856

Law, P. K. (2010). A Theory of Reasoned Action Model of Accounting Students' Career Choice in Public Accounting Practices in the post-Enron. Journal of Applied Accounting Research, 11(1), 58-73.

Malthus, S., \& Fowler, C. (2009). Perceptions of Accounting: A Qualitative New Zealand Study. Pacific Accounting Review, 26-47.

Mam Yudi, M., Ahmad, M., Sahol Hamid, N., Yatim, N., \& Abdullah, A. (2018). Exploration of Study Skills among Professional Accounting Students: Evidence from Malaysian Public University. Voice of Academia 13 (2) 2018, 71-84, 71-84.

Mazlina Mustapha, \& Mohammad Hasmawi Abu Hassan. (2012). Accounting Students' Perception on Pursuing. International Journal of Education, 4(4), 1. doi:ISSN 1948-5476

MIA (2018), Laporan Bersepadu 2018, MIA

MIA. (2019), 'Keynote Address by Dr Nurmazilah Dato' Mahzan, Chief Executive Officer, Malaysian Institute of Accountants - The Kaplan Forum: Educating Future Accountants", Retrieved from https://www.mia.org.my/v2/highlights/content_display.aspx?ID=N15353635M.

Odia, J. O., \& Ogiedu, K. O. (2013). Factors Affecting the Study of Accounting in Nigerian Universities. Journal of Educational and Social Research. https://doi.org/10.5901/jesr.2013.v4n3p89

Owusu, G., Obeng, V., Ofori, C., Ossei Kwakye, T. and Bekoe, R. (2018), "What Explains Student's Intentions to Pursue A Certified Professional Accountancy Qualification?", Meditari Accountancy Research, Vol. 26 No. 2, pp. 284-304

Performance Management and Delivery Unit (PEMANDU), P. M. (2010, October 26). Economic Transformation Programme: A Roadmap for Malaysia. Retrieved from https://policy.asiapacificenergy.org/sites/defaultfiles/ETP.pdf

Pratama, A., \& Padjadjaran, U. (2017). Why Do Accounting Students Choose a Career in Accountancy? An Exploratory Study in Bandung City, West Java, Indonesia. Review of Integrative Business and Economics Research, 6(2), 393-407.

Ryan, R. M., \& Deci, E. L. (2000). Intrinsic and Extrinsic Motivations: Classic Definitions and New Directions. Contemporary Educational Psychology. https://doi.org/10.1006/ceps.1999.1020

Santos, E. A. dos, Moura, I. V., \& Almeida, L. B. de. (2018). Students' Intention to Pursue a Career in Accounting from the Perspective of the Theory of Planned Behavior. Journal of Education and Research in Accounting, 12(1), 63-78.

Stuart, P., \& Gonzalez, M. (2016). Global Trends in Professional Accountancy Education. Kaplan Publication. 